\title{
Pharmacognostical and Physicochemical Analysis of Cleome viscosa L. Seeds
}

\author{
Harpreet Singh ${ }^{1}$, Amrita Mishra ${ }^{2}$, Arun Kumar Mishra ${ }^{1}$
}

\section{Harpreet Singh', Amrita Mishra², Arun Kumar Mishra' \\ 'Department of Pharmaceutical Chemistry, School of Pharmaceutical Sciences, IFTM University, Moradabad, 244102, Uttar Pradesh, INDIA. 2Department of Pharmacognosy, School of Pharmaceutical Sciences, IFTM University, Moradabad-244102, Uttar Pradesh, INDIA}

\section{Correspondence}

Harpreet Singh*, Department of Pharmaceutical Chemistry, School of Pharmaceutical Sciences, IFTM University, Moradabad-244102, Uttar Pradesh, INDIA.

Phone no: 91-0591-2360817

E-mail: harpreetproctor@rediffmail.com

History

- Submission Date: 26-12-16;

- Review completed: 05-01-17;

- Accepted Date: 02-02-17.

DOI : 10.5530/pj.2017.3.63

Article Available online

http://www.phcogj.com/v9/i3

\section{Copyright}

(C) 2017 Phcog.Net. This is an openaccess article distributed under the terms of the Creative Commons Attribution 4.0 International license.

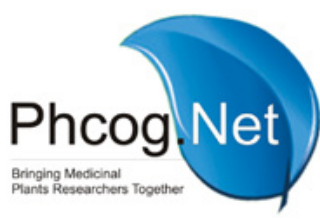

\begin{abstract}
Aim: The seeds of Cleome viscosa L. are used to treat tumor, emesis, diarrhea, epilepsy and hyperthermia. Seeds are used to heal wound also. In order to ensure the use of only genuine and uniform material in treatment of ailments by herbs and herbal formulations, pharmacognostical standardization and physiochemical parameters evaluation is needed. Methods: Morphological and powder microscopic characters of seed powder were studied. The physiochemical parameters studied were LOD, total ash, acid insoluble, water soluble, sulphated ash, extractives, volatile oil content and crude fibre content etc. Further, florescence analysis and element analysis of seed powder was performed by undergoing chemical reaction +UV method and EDAX method respectively. Results: Brown colored seeds with rough seed surface with seed size $0.1 \mathrm{~cm}$ were recorded. The pods were brown coloured when air dried. They were $4-5 \mathrm{~cm}$ long containing 8-12 small seeds. Powder microscopic study revealed the presence of fragment of epidermis of testa, groups of cells resembling like stone cells and irregularly shaped protein bodies were observed. Florescence Analysis revealed the presence of chromophores. EDAX analysis showed the presence of $\mathrm{Mg}, \mathrm{Al}, \mathrm{Si}, \mathrm{S}, \mathrm{Cl}, \mathrm{K}, \mathrm{Ca}$ and $\mathrm{Cu}$ etc in different amount. Conclusion: Pharmacognostical and physiochemical parameters were established which would facilitate quick identification and selection of the herbal drugs from various adulterants.
\end{abstract}

Key words: Cleome viscosa L., Macroscopic, microscopic, physicochemical, Crude fibre.

\section{INTRODUCTION}

The study of plant drugs from the pharmacognostical stand point would include the study of the habitat, general characters of the plant from which the drug is derived, its place in the botanical system, the organ or the organs of the plant used, their gross, minute structures in the whole and in the powdered conditions and the chemistry of the constituents especially of those which may be used in therapeutics. The macroscopic and microscopic description of a medicinal plant is the first step towards establishing the identity and the purity of such materials. ${ }^{1}$ This should be performed before any tests are undertaken. The importance of pharmacognosy has been widely felt in recent times. Unlike taxonomic identification, pharmacognostic study includes parameters which help in identifying adulteration from powdered drug also. $^{2}$

Pharmacognostical and physiochemical studies are important because once the plant is dried and powdered, it loses its morphological identity and easily prone to adulteration. Pharmacognostic studies ensures plant identity, lays down standardization parameters which prevent the drug from adulterations. Such study helps in authentication of the plants and ensures reproducible quality of herbal products, which lead to safety and efficacy of natural products. ${ }^{3}$
On another hand, the physicochemical evaluation of the plant material is mandatory also in order to detect adulteration or improper handling of drugs. The parameters which are studied includes moisture content, loss on drying (LOD), total ash, acid-insoluble ash, water soluble ash value, alcohol and water-soluble extractive values, etc. ${ }^{4}$

Ash values are used to determine quality and purity of crude drug. It indicates presence of various impurities like carbonate, oxalate and silicate. The water soluble ash is used to estimate the amount of inorganic compound present in drugs. The acid insoluble ash consists of mainly silica and indicates contamination with earthy material. Moisture content of drugs should be at minimal level to discourage the growth of bacteria, yeast or fungi during storage. Estimation of extractive values determines the amount of the active constituents in a given amount of plant material when extracted with a particular solvent. ${ }^{5}$

Cleome is well known for the therapeutic efficacy of its different species. One of the most important species of this genus is Cleome viscosa L. Cleome viscosa L. is called 'Hurhur' in India. Traditionally Cleome viscosa Linn. plant is an antimalarial drug and beneficial in blood diseases and uterine complaints also. The pungent seeds and seed pods are used as sub- 
stitute of mustard in curries. In traditional system of medicine, leaves, seeds and roots of the plant are widely used as an anthelmintic, antiseptic, cardiac stimulant, carminative, anticonvulsant, antidiarrhoeal, antipyretic and are also used to treat skin diseases. ${ }^{6,7}$ In previous phytochemical studies, Cleome viscosa L. seeds have been reported to contain Oct-1-ene, Heptane-4-one, Heptane-2-one, Non-1-ene, a-pinene, dehydrosabenene, 6-Methylhept-5-ene-2-one, E-ocimene, myrcene, p-cymene, limonene, dehydrolinalool, undecan, limonene oxide, a-tepeniol, benzoic acid, Deca-2,4-dien-1-al, Decan-2- ol, Gerniol, Undec-10-e-1al. ${ }^{8}$ The literature survey reveals that there is no systematic pharmacognostical and physiochemical study for Cleome viscosa L. seeds has been undertaken yet. In the present communication, the study was performed on the pharmacognostic and physiochemical parameters of the seeds of Cleome viscosa $\mathrm{L}$.

\section{MATERIALS AND METHOD}

All the chemicals and reagents used were of analytical grade purchased from CDH Laboratories Pvt. Ltd., New Delhi, India.

\section{Collection and Authentication}

The mature seeds of Cleome viscosa L. were collected from nearby areas of Moradabad in month of September. Care was taken to select normal and even size seeds while collection. The collected seeds along with plant specimen were authenticated by renowned botanist Dr. G.P. Sinha (Scientist D), Botanical Survey of India (BSI), Allahabad, India and a voucher specimen (TR No. GG 950204) was deposited in office of Botanical Survey of India, Allahabad, India.

\section{Macroscopic Studies}

Macroscopical evaluation refers to evaluation of drugs by color, odour, taste, shape and special features like touch and texture. It is a technique of qualitative evaluation based on the study of morphological profiles of the seeds. The dried seeds were taken for macroscopical evaluation. ${ }^{9-11}$

In order to evaluate the macroscopical features of seeds, number of seeds in the pods, size and color of pods of the Cleome viscosa L. species were observed (Figure 1). Findings of macroscopic characters are presented in Table 1.

\section{Microscopic Studies}

In powder microscopic study, powder of dried seeds was taken. Cleome viscosa L. seeds were powdered using mixer grinder. The coarse powdered material thus obtained, sieved with the help of $40 \mathrm{~mm}$ sieve for

Table 1: Physicochemical parameters of the seeds of Cleome viscosa L.

\begin{tabular}{ccc}
\hline S. No & Physicochemical Parameters & $\begin{array}{c}\text { Percentage (Mean } \pm \\
\text { SEM) }\end{array}$ \\
\hline 1. & Loss on Drying (LOD) & $4.85 \pm 0.321 \%$ \\
2. & Total ash value & $5.2 \pm 0.385 \%$ \\
3. & Acid insoluble ash value & $0.51 \pm 0.0211 \%$ \\
4. & Water soluble ash value & $1.78 \pm 0.0213 \%$ \\
5. & Sulphated Ash & $4.98 \pm 0.366 \%$ \\
6. & Alcohol soluble extractive value & $38.8 \pm 0.852 \%$ \\
7. & Water soluble extractive value & $15.8 \pm 0.514 \%$ \\
8. & Ethyl acetate soluble extractive value & $10.50 \pm 0.986 \%$ \\
9. & Petroleum ether soluble extractive value & $18.67 \pm 0.881 \%$ \\
10. & Volatile oil content & $0.88 \pm 0.0034 \%$ \\
11. & Crude fibre content & $28.9 \pm 0.889 \%$ \\
\hline
\end{tabular}

powder microscopy. For microscopical characters of purified powder samples, slides were prepared by using water, chloral hydrate as a clearing agent and glycerin as mounts. All powder samples were stained with various reagents as per the textual reference. ${ }^{12}$

\section{Physicochemical Parameters}

Physicochemical parameters were studied for the seeds of $C$. viscosa. The procedures recommended in $\mathrm{WHO}$ guidelines were followed to evaluate the physicochemical constants. ${ }^{13}$ Findings are presented in Table 1.

\section{Fluorescence Analysis}

$0.5 \mathrm{~g}$ of seed powder were taken into clean test tubes. In each tube, $5 \mathrm{ml}$ of different solvents were added and the tubes were shaken. The samples in test tubes were allowed to stand for about $20-25 \mathrm{~m}$. The solutions obtained were observed under the UV visible light for their characteristic colour reaction and were compared with a standard colour chart. The observed colors were recorded. Same procedure was repeated for different extracts obtained from seeds of Cleome viscosa. The results are presented in Table 2.

\section{Elemental Analysis}

For seeds of Cleome viscosa L. spectra of the various micro mineral elements and macro mineral elements viz. carbon $(\mathrm{C})$, oxygen $(\mathrm{O})$, magnesium $(\mathrm{Mg})$, aluminium $(\mathrm{Al})$, silicon $(\mathrm{Si})$, sulphur $(\mathrm{S})$, chloride $(\mathrm{Cl})$, potassium $(\mathrm{K})$, calcium $(\mathrm{Ca})$ and copper $(\mathrm{Cu})$ were generated by energy dispersive X-ray spectroscopy (EDAX) technique. The results are presented in Table 3 .

\section{RESULT AND DISCUSSION}

\section{Macroscopic Studies}

Cleome viscosa L. seeds were brown coloured. They were odourless, tasteless, looking like snail shell. Their surface was rough. Size was 0.1 $\mathrm{cm}$. The pods were brown colored when air dried. They were $4-5 \mathrm{~cm}$ long and contained 8-12 small seeds. These macroscopic characters of Cleome viscosa L. seeds are presented in Figure 1.

Microscopic Studies

For microscopy, seed powder was taken on glass slide and observed under light microscope. Number of fragments of epidermis testa consisting of thin-walled, polygonal cells and groups of cells, resembling like stone cells of reddish-brown color were observed. Large number of oval, rounded or irregularly shaped protein bodies were also observed. Starch 
grains and crystals of calcium oxalate were found to be absent. Figure 2(A-C) (10X45X)

\section{Physicochemical Studies}

The results of physicochemical characters such as LOD, total ash, acid insoluble ash, water soluble ash, sulphated ash, percentage of extractive values in various solvents such as alcohol, water, ethyl acetate, petroleum ether, volatile oil content and crude fiber content of the seeds powder of Cleome viscosa L. are presented in Table 1.

Excessive amount of water present in plant drugs is the cause for bacterial and fungal growth as well as responsible for the hydrolysis of constituents. The pharmacopoeial monographs limit the water content, especially in drugs that have the facility to absorb it, or in which the excessive amounts of water cause deterioration. In the present study, loss on drying was found to be $4.85 \pm 0.321 \%$.

Ash determination includes determination of total ash, sulfated ash (residue on ignition) and acid insoluble ash. The total ash involves the determination of physiological and the non-physiological ash. After drug calcinations, the amount of non volatilized residue was found to be 5.2 $\pm 0.385 \%$. After calcination with concentrated sulfuric acid, non volatilized residue represents sulphated ash. The metals present in the drug gets converted to sulfates, as these are more stable to heat and allow more accurate results than those obtained by simple calcination. The sulfated ash value was found to be $4.98 \pm 0.366 \%$. The acid insoluble ash is the residue, obtained after boiling total ash with dilute hydrochloric acid, filtrating to remove the soluble and igniting the remaining insoluble matter. Thus by this procedure, level of silica is determined, specially sand and siliceous earth content present in the drug. Acid insoluble ash value was found to be $0.51 \pm 0.0211 \%$. Any significant deviation in the $\%$ of ash value reported in present research work clearly shows adulteration of the drug. Extractable matter determination was carried out to determine the drug active constituents. Substances are generally extracted with water, methanol, petroleum ether and other solvents to determine extractive matters. Cleome viscosa L. seed's extractive value was found to be $38.8 \pm 0.852 \%$ in alcohol, $15.8 \pm 0.514 \%$ in water, $10.50 \pm 0.986 \%$ in ethyl acetate and $18.67 \pm 0.881 \%$ in petroleum ether. The maximum value was found to be with alcohol.

In many plants, the volatile constituents i.e. essential oils are present and characterized the mixture of terpenes, sesquiterpenes and their oxygenated derivatives, aromatic compounds, which are oily and volatize at room temperature. Pharmacologically active substances may also pres- ent in essential oils. The volatile content was found to be $0.88 \pm 0.0034 \%$ in Cleome viscosa L. seeds.

\section{Fluorescence Analysis}

Fluorescence analysis of powdered seeds and different extracts of the seeds of Cleome viscosa L. with different reagents were carried out to observe the color reactions (Table.2) and to record presence of chromophore.

\section{Elemental Analysis}

Elemental analysis of Cleome viscosa L. seeds was done to find out weight $\%$ of elements present in seeds (Table.3, Figure 3).

The mineral constituent present in Cleome viscosa L. seeds indicates its ethnopharmacological and nutritional importance. High peaks of carbon, oxygen, showed that these elements are present in very large

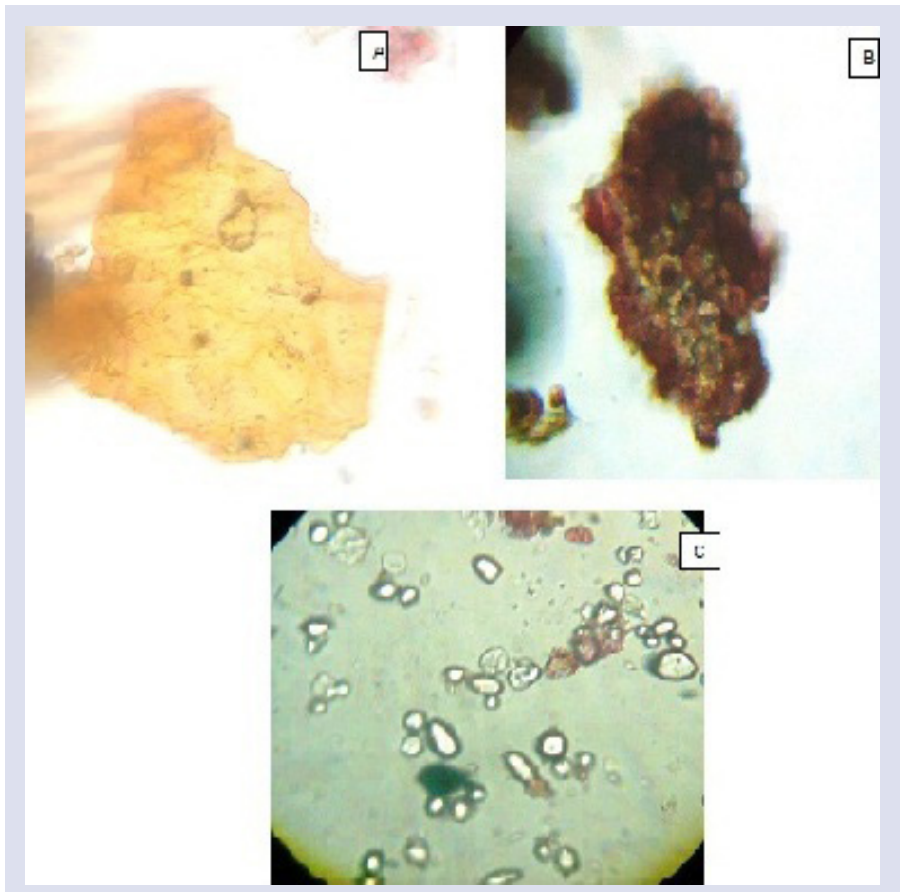

Figure 2: A) Fragments of epidermis of testa, B) Groups of cells resembling like stone cells, C) Irregularly shaped protein bodies.

Table 2: Findings of Florescence Analysis

\begin{tabular}{ccccc}
\hline S. No. & Reagents & Day light & Short UV (254nm) & Long UV (365nm) \\
\hline 1 & Distilled water & Brown & Brown & Dark brown \\
2 & Powder $+1 \mathrm{~N} \mathrm{HCl}$ & Pale Yellow & Pale Green & Pale Green \\
3 & Powder $+1 \mathrm{~N} \mathrm{NaOH}$ & Red & Brownish Green & Brownish Green \\
4 & Powder $+50 \% \mathrm{HCl}$ & Frownish Green & Brown & Fluorescent Green \\
5 & Powder $+50 \% \mathrm{H} 2 \mathrm{SO} 4$ & Dark brown & Greenish & Brown \\
6 & Powder+ & Greenish & Brown & Dark brown \\
& Methanol+50\% HNO3 & Brown & Greenish & Greenish \\
7 & Powder + Methanol + & Brown & Brown & Brown \\
9 & 1 N NaOH & & Brown & Brown \\
10 & Aqueous extract & Light Brown & Greenish fluorescence & Greenish fluorescence \\
11 & Methanolic extract & Greenish brown & Greenish brown & Greenish brown \\
\hline
\end{tabular}




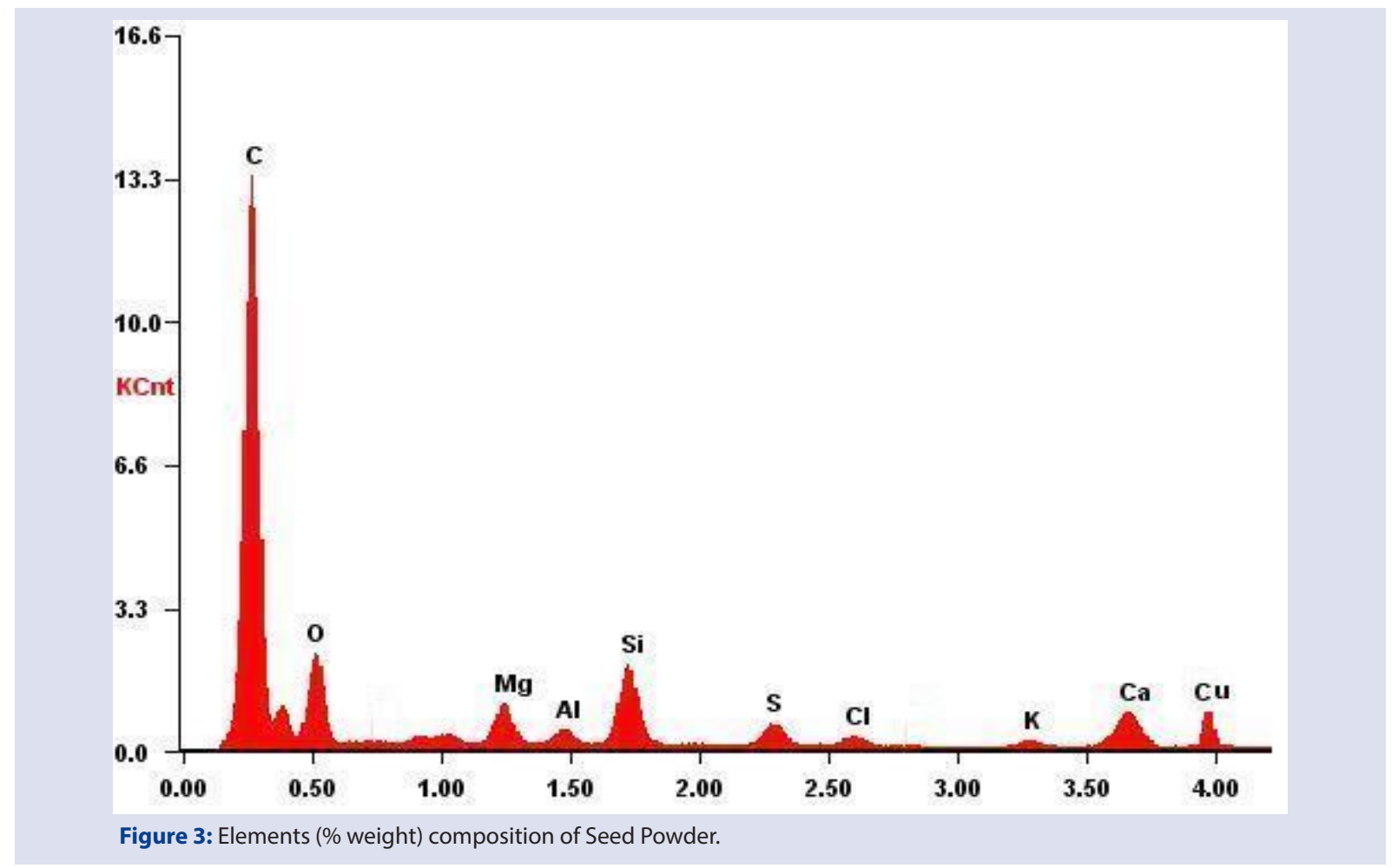

Table 3: Elements Analysis Result

\begin{tabular}{ccc}
\hline S. No. & Element & Weight \% \\
\hline 1 & $\mathrm{C}$ & 66.80 \\
2 & $\mathrm{O}$ & 12.40 \\
3 & $\mathrm{Mg}$ & 03.20 \\
4 & $\mathrm{Al}$ & 01.90 \\
5 & $\mathrm{Si}$ & 07.60 \\
6 & $\mathrm{~S}$ & 01.20 \\
7 & $\mathrm{Cl}$ & 00.70 \\
8 & $\mathrm{~K}$ & 00.90 \\
9 & $\mathrm{Ca}$ & 03.20 \\
10 & $\mathrm{Cu}$ & 02.10 \\
\hline
\end{tabular}

amount. For instance, magnesium, calcium, copper and silica were in limited amounts. Aluminium and sulphur were found in less amounts (Figure 3). All of these mineral elements have different metabolic roles in human body.

For example, calcium is an important element which is known for reducing the risk of large variety of non-infectious diseases like maintenance of bones, teeth and muscles. ${ }^{14,15}$ Acid-base balance and blood pressure is regulated with an important mineral which is potassium. ${ }^{16}$ Magnesium is an important "helper molecule" of many enzymes mainly involved in energy metabolism, production of protein and for maintaining electrical potential of nerve tissue and cell membranes. ${ }^{17}$ There is an important role of sulphur in synthesis of protein, regeneration of cells and cleansing of blood. ${ }^{18}$ The presence of these important elements in Cleome viscosa Linn. seeds accounts for the therapeutic use as antipyretic, antimicrobial, analgesic, antiemetic, anticonvulsant and psychopharmacological, anthelmintic, carminative, anticonvulsant, wound healing.

\section{DISCUSSION}

The evaluation of pharmacognostical parameters was performed on the basis of detailed botanical evaluation of the seeds which included morphology and microscopy as well as WHO recommended physicochemical parameters. ${ }^{19}$ The findings of the pharmacognostical evaluation may be useful to identity of the seeds of C. viscosa (Linn.) which may produce a solid basis for the authenticity of the plant and also to distinguish the seeds of $C$. viscosa seeds other similar species. ${ }^{20,21}$ The macroscopic characters were examined to identify the seed of the C. vis$\cos a$. The powder characters of a drug are mainly used in the identification of the drug in the powder form. The seeds powder was dark brown in colour with no specific odour and taste. The microsocopical features of the powder which were observed, which showed numerous epidermis of testa, groups of cells resembling like stone cells and irregularly shaped protein bodies (Figure 3.3-3.5).

The physicochemical parameters play a vital role in evaluating the purity and quality of the drug. ${ }^{22}$ Ash values are useful in evaluating the quality and purity of crude drugs, especially in powder form. ${ }^{23}$ The ash values are important since ash may be derived from the plant itself (physiological or natural ash) as well as from the extraneous matter, especially sand and soil adhering to the surface of the drug (non physiological ash). ${ }^{24}$ The determination of physiological and non physiological ash is termed as total ash. ${ }^{25}$ The total ash may vary within wide limits for specimen of genuine drug due to variable natural or physiological ash, ${ }^{26}$ in such cases the ash obtained is treated with acid in which most of the natural ash is soluble leaving the silica as acid-insoluble ash which represents most of the ash from the contaminating soil. ${ }^{27}$ The ash values of the powdered seeds suggests about a high percentage of sulphated ash. Any significant variation in the percentage of ash as reported in the present work may show the sign of adulteration of the drug. In present study, all the above parameters were studied. ${ }^{28}$

Extractive values indicates about the chemical constituents present in the drug as well as useful in the determination of exhausted or adulterated drugs. ${ }^{29,30}$ The results indicates that the powdered seeds have high alco- 
hol soluble extractive value. The loss on drying reveals the percentage of moisture present in the drug, since moisture facilitates the enzyme hydrolysis or growth of microbes which leads to deterioration. Fluorescence analysis of powdered seeds was studied in both UV and day light. The powder showed green fluorescence with methanol in UV light at 254 $\mathrm{nm}$, which indicates the sign of chormophore in the drug. The elemental analysis revealed the presence of some important elements.

\section{CONCLUSION}

The detailed pharmacognostical studies on the seeds of C. viscosa may substantiate as an essential data for the identification of raw material and also used to differentiate the plant from its allied species and adulterants.

\section{ACKNOWLEDGEMENT}

The authors are thankful to Prof. R.M Dubey, Vice Chancellor, IFTM University, Moradabad for providing. Unique Laboratory facilities to conduct the research work. The present paper is a part of Ph.D work from IFTM University, Moradabad.

\section{CONFLICT OF INTEREST}

None

\section{ABBREVIATIONS USED}

EDAX: Energy Dispersive X-ray Spectroscopy; UV: Ultra Violet, LOD: Loss on Drying.

\section{REFERENCES}

1. Sundar S, Pillai YJK. Pharmacognostic and physicochemical evaluation of Solanum virginianum L. leaves (solanaceae). Int J Pharm Bio Sci. 2016;7(1):40-4

2. Sirajudeen J, Ahamath JM. Evaluation of pharmacognostic, physicochemical studies and heavy metal analysis of medicinal plant solanum erianthum $d$. Don World J Pharm Pharm Sci. 2014;3(5):1601-6.

3. Sumitra C, Dishant D, Disha M. Pharmacognostic, phytochemical, physicochemical and fluorescence analysis of Terminalia bellerica leaf and stem. World J Pharm Sci. 2014;2(4):390-6.

4. Ali W, Shaikh H, Abdullah A, Khanam S. Standardization of unani antidiabetic tablet - Qurse Tabasheer. Pharmcog Res. 2016;8(2):147-2. https://doi. org/10.4103/0974-8490.175611 PMid:27034607 PMCid:PMC4780142.

5. Chanda S. Importance of pharmacognostic study of medicinal plants: An overview. J Pharm Phytochem. 2014;2(5):69-3

6. Mohtasheem UHM, Salman A, Munnawar S, lqbal A. Analgesic and Antiemetic activity of Cleome viscosa L. Pak J Bot. 2011;43(1):119-2.

7. Nowshehri JA, Bhat ZA, Shah MY. Pharmacognostic Standardisation and Phytochemical Evaluation on the Seeds of Two Vitis Vinefera L. Varieties Grown in Kashmir Valley, India. Pharmacogn. J. 2016;8(5):465-70. https://doi.org/10.5530/ pj.2016.5.9.

8. Gabriel O, Peter W, Stephen O. Chemical investigation of volatile constituents of Cleome viscosa from Nig. Bull. Chem. Soc. Ethop. 2005;19(1):139-3

9. Mathew KM. The flora of Tamil nadu Carnatic. Rapinat Herbarium, St. Joseph's
College, Tiruchirapalli, India. 1983;1:226-7.

10. Hajra PK, Nair VJ, Daniel P. Flora of India, Botanical Survey of India. 1997:4:431 2.

11. Gamble JS, Stephen TD, Fischer CEC. Flora of the Presidency of Madras, Botanical Survey of India. 1967;1:170-1.

12. Ray FE, Esau K. Plant Anatomy, John Wiley and sons, New York. 1965:767.

13. Khandelwal KR. Practical Pharmacognosy. Nirali Prakashan, 21 st edition, Pune. $2011 ; 23: 1-12$.

14. The Ayurvedic Pharmacopoeia of India, India Dept. of Indian Systems of Medicine \& Homoeopathy, Govt. of India, Ministry of health and family welfare. 1989;1:139-43.

15. Vaskonen T. Dietary minerals and modification of cardiovascular risk factors. $J$ Nutr Biochem. 2003;14(9):492-6. https://doi.org/10.1016/S0955-2863(03)000743.

16. Nieves JW. Osteoporosis: the role of micronutrients. Am J Clin Nutr. 2005;81(5):1232S-9S. PMid:15883457.

17. Weaver CM. Potassium and Health. Adv Nutr. 2013;4(3):368S-7S. https://doi. org/10.3945/an.112.003533 PMid:23674806 PMCid:PMC3650509.

18. Mohammed MI, Sharif N. Mineral Composition of Some Leafy Vegetables Consumed in Kano, Nigeria. Nig J Bas App Sci. 2011;19(2):208-2.

19. Afolayan AJ, Otunola GA. Ultrastructure and Elemental Analysis of Hypoxis Hemerocallidea: A Multipurpose Medicinal Plant. Afr J Tradit Complement Altern Med. 2014;11(4):39-3. https://doi.org/10.4314/ajtcam.v11i4.6.

20. Priyadarsini SS, Vadivu R, Jayshree N. Pharmacognostical Standardization of Leaves of Ravenala madagascariensis Sonn. Res J Pharmacog Phytochem. 2010;2(4):288-2.

21. Singh S, Semwal BC, Neeli GS. Microscopic and Physicochemical Evaluation of Leaves of Sphaeranthus indicus Linn. Pharmacogn J. 2017;9(1):21-6. https://doi. org/10.5530/pj.2017.1.4.

22. Ramasheshan ST, Pitchaiah P, Maramreddy PR, Bharti V, Ramakrishana KK, Gaddam V, Tewari D, Mangal AK, Padhi MM, Dhiman KS. Pharmacognostical Standardization of Goraksha pods: an important Nutritive and antidiabetic Plant. Pharmacogn. J. 2016;8(5):424-9. https://doi.org/10.5530/pj.2016.5.2.

23. Ranjan $V_{\text {, Vats }} M$. Pharmacognostical and physico-chemical standardisation of whole plant of adiantum capillus veneris linn. Inter J Pharm Sci Res. 2016;7(2):773-2

24. Pal VC, Singh B, Ahamad A. Pharmacognostic Evaluation of Leaves and Stem of Murraya koenigii. UK J Pharm Biosci. 2015;3(1):37-1. https://doi.org/10.20510/ ukjpb/3/i1/89265.

25. Arumugam S, Natesan SK. Pharmacognostical Studies and Phytochemical Investigation of Barleria noctiflora Linn (Acantheceae). Inter J Pharmcog Phytochem Res. 2015;7(3):450-6.

26. Joshi AB, Surlikar PM, Bhobe M. Physicochemical and phytochemical investigation of the roots of Ixora Coccinea linn. Der Pharm Chem. 2013;5(4):112-5.

27. Bhargava VV, Saluja AK, Dholwani KK. Detection of Heavy Metal Contents and Proximate Analysis of roots of Anogeissus latifolia. J Pharmacog Phytochem. 2013;1(6):61-5.

28. Sarvesh K, Maurya SK, Seth A, Singh AK. Quality control standardization of the bark of Moringa oleifera lam. Inter J Pharm Pharm Sci. 2014;7(1):56-0.

29. Ariharan VN, Meena Devi VN, Gopu Kumar ST, Nagendra Prasad P. Physicochemical properties of Bio-diesel obtained from Callophyllum innophyllum oil. Res J Pharm Bio and Chem Sci. 2014;5(1):64-1.

30. Vadivu R, Jayshree N, Kasthuri C, Rubhini K, Rukmankathan G. Pharmacognostical standardization of leaves of Ixora coccinea linn. J Pharm Sci Res. 2009:1(4):151-7

\section{SUMMARY}

- In order to ensure the use of only genuine and uniform material in treatment of ailments by herbs and herbal formulations, pharmacognostical standardization and physiochemical parameters evaluation is required

- Morphological and powder microscopic characters of seed powder were studied. The physiochemical parameters studied were LOD, total ash, acid insoluble, water soluble, sulphated ash, extractives, volatile oil content and crude fibre content etc.

- Further, florescence analysis and element analysis of seed powder was performed by undergoing chemical reaction +UV method and EDAX method respectively.

- Brown colored seeds with rough seed surface with seed size $0.1 \mathrm{~cm}$ were recorded. The brown coloured pods were 4-5 cm long containing 8-12 small seeds. Powder microscopic study revealed the presence of fragment of epidermis of testa, groups of cells resembling like stone cells and irregularly shaped protein bodies were observed.

- EDAX analysis showed the presence of $\mathrm{Mg}, \mathrm{Al}, \mathrm{Si}, \mathrm{S}, \mathrm{Cl}, \mathrm{K}, \mathrm{Ca}$ and $\mathrm{Cu}$ etc in different amount. 


\section{ABOUT AUTHORS}

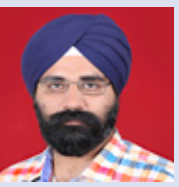

Mr. Harpreet Singh: Obtained his M. Pharm degree in Pharmaceutical Chemistry in 2012 from U PTechnical University, Lucknow. $\mathrm{He}$ is currently working on the post of Assistant Professor in School of Pharmaceutical Sciences, IFTM University, Moradabad. He has to his credit 10 national and 8 internation research paper. He works in the area of synthetic medicinal chemistry, Phytochemistry and structure elucidation. He has supervised 10 scholars of Underghraduate and Post Graduate. Mr. Singh is undergoing Ph.D from IFTM University, Moradabad under supervision of Dr. Arun K Mishra.

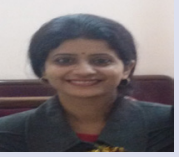

Dr. Amrita Mishra: Phd from Birla institute of technology, Ranchi is working as a Assistant Professor at School of Pharmaceutical Sciences IFTM University, Mordabad. She works in the area of Herbal drug standardization, Phytochemistry and Pharmcology. She have great knowledge of writing projects and research papers.

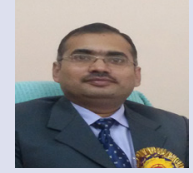

Dr. Arun Kumar Mishra did B. Pharm and M. Pharm from UP Technical University, Lucknow and Ph.D from B. University, Ajmer Raj Dr. Mishra is recipient of fellowship from AICTE, Govt. Of India, New Delhi. Currently, he is working as Assistant Professor and Head of Department, IFTM University, Moradabad. Dr. Arun K Mishra has also received grant from DBT, New Delhi and conducted Workshop. He has, to his credit 64 research papers in International and National journals of high repute with very good impact factor. He has presented 36 poster presentations in various National and International conferences. Dr. Mishra has supervised 10 post graduate dissertations. At present, 2 post graduate students and $5 \mathrm{Ph}$.D research scholars are working under his supervision

Cite this Article: Singh H, Mishra A, Mishra AK. Pharmacognostical and Physicochemical Analysis of Cleome viscosa L. Seeds. Pharmacogn J. 2017;9(3):372-7. 